\title{
The Wit in the Dungeon: Leigh Hunt in Surrey Gaol
}

In March 1812, Leigh Hunt, writing in his radical London newspaper, the Examiner, described the prince regent as a violator of his word and a disreputable libertine. After anxious months of waiting, in February 1813 he was convicted of seditious libel and sentenced to two years in prison. Leigh Hunt's first days in Surrey Gaol were unbearable. For the past seven years-since about his twenty-first birthday-he had suffered from nervous attacks, experiencing palpitations, flickering eyes, nausea, headaches, throat stiflings, and uncontrollable anxiety. When he felt an attack coming on, he walked to and fro about his prison cell to break its force. In this physical and mental condition prison proved a considerable ordeal. The one sustaining asset was his capacity for suffering: a trait that he had inherited from his mother and which had been inculcated-as he put it -from his cradle. To suffer for a cause was his pride and almost his joy. That his wife and family did not entirely share his emotions was a fact he often found difficult to comprehend.

In March 1813, he presented a petition to the prison authorities begging, on account of his health, the society of his young wife, Marianne, and his two small sons, and frequent visits from his friends. The petition was granted, and Marianne and baby John joined him in his dreary cell where, as his wife prepared a frugal supper of gruel, he settled down briefly to keep a journal describing his thoughts and activities. In April his position improved when the prison governor allotted him rooms in the prison infirmary with an adjoining patch of garden. Workmen transformed these rooms into a poetic bower, papering the walls with a trellis of roses, painting the ceiling with clouds and a sky, and planting the garden into a flowering meadow. Hunt disguised the barred windows with Venetian blinds, brought in books, pictures, and a bust of Homer sculpted by Marianne, and hired 
a piano and a servant. There was "no other such room except in a fairy tale."I

While conditions improved for Hunt, they deteriorated for his wife. Their elder child, three-year-old Thornton, ill even before the trial, grew worse in prison. By day he suffered from nervous grimacing and a nervous habit of striking things; at night he ran fevers and suffered nightmares, even though, as Charles Lamb noted, this "nursechild of optimism" had been scrupulously shielded from all conventional childhood bogeymen. ${ }^{2}$ Despite happy daily walks with his father when they watered the little boy's favorite sunflower plant, and jolly games of battledore and building bricks, poor little Thornton faded before his parents' eyes. The only remedy, according to the doctors, was a course of soothing powders and regular sea bathing. A seaside holiday was prescribed. Marianne dreaded it, picturing Hunt's agony of separation, but clearly she had no choice. In April 1813 , taking baby John and the adolescent daughter of a friend as nurse-maid and companion, Marianne and Thornton left for Brighton, the home of Marianne's girlhood.

A long sequence of letters describes that seaside visit and the thoughts and activities of both the correspondents. Carefully collected by Luther A. Brewer, of Cedar Rapids, Iowa, they now reside in the Brewer-Leigh Hunt Collection at The University of Iowa Libraries. They are important letters: tender, frank, detailed, re-creating with striking immediacy those lonely months of April, May, and June. Hunt had spent the seven years of their courtship teaching Marianne to write letters, and though her spelling and expression were still shaky and her interests narrowly domestic, she had learned very ably what her husband wanted to hear. "Say what you feel," he told her, ${ }^{3}$ and she did. Indeed there were times when her longing became "outrageous"; when she saw their hearts and bodies united ... "you know what I mean . . . I must not think about it." 4 The "pleasure of hearing about it," wrote Hunt, "almost overbalances the pain." For an intimate baring of feelings biographers must bless Marianne. In this, her letters are often richer than those of her literate and cultivated husband.

1 Leigh Hunt, The Autobiography of Leigh Hunt, ed. J. E. Morpurgo (London: Cresset Press, 1949), p. 243.

2 Charles Lamb, Essays of Elia (London: Oxford University Press, 1906), p. 91.

3 Leigh Hunt to Marianne Hunt, April 29, 1813. All letters directly quoted are in the Brewer-Leigh Hunt Collection in The University of Iowa Libraries.

4 Marianne Hunt to Leigh Hunt, May 16, 1813. Few of Marianne Hunt's letters survive, so these are especially valuable.

5 Leigh Hunt to Marianne Hunt, May 5, 1813. 
The separation began badly for both. Hunt was so devastated by loneliness that he almost called her back, and the sight of his son's empty bed sent him into lamentations. Marianne too was depressed. Brighton recalled disquieting memories, for Marianne's father, an improvident linen draper, had lost his money there and quarreled with friends and relatives. Every step reminded her of things and people she wanted to forget. Marianne's days were dismal, rigidly regulated by the needs of two small children. She rose at five, breakfasted at a quarter to eight, walked the children until eleven, then ate bread and rested. At half past twelve they were out again, and John, and later Thornton, had a daily sea bath. At two they dined, at four they walked, and at six returned to tea and bed for the boys. At nine Marianne had beer and a crust of bread and at ten she was in bed. It was no lively existence.

Worse was to come. In early May, she felt sick and faint and feared she was pregnant. "Oh Henry!" she wrote bravely to her husband, "if we should have a dear little girl," 6 but her private feelings were less cheerful. The necessity of quickly weaning baby John produced milk fever. One evening her temperature soared and she fell into a type of fit. She was in agony lest Hunt, already testy from her protracted absence and his own illness, should be alarmed, and she made light of it, but clearly she was decidedly ill. At least Thornton was improving. Tepid sea baths improved his appetite and he rode on donkeys and played like a normal three-year-old boy. He also succeeded splendidly with the Greek words his father sent him to learn daily. And he regularly wrote to his papa, using the ink pot his proud parent had sent to him. Each night he prayed that God would make dear papa well, and so did Marianne. In fact, the letters of husband and wife frequently ended with an invocation of God's blessing, contradicting those who labeled Hunt at this stage of life as an atheist. Hunt, who doted on his son, calling him his "dear, dear boy, the very thought of whom makes the tears start in my eyes," was overjoyed at Thornton's improvement and sent him many loving messages.

At last it seemed as if the little family might be reunited. Then Thornton caught chicken pox: "so disfigured you would hardly know him" and, despite a raging fever, "patient as a lamb." John, too, was cutting teeth and fretful. "Oh," cried Marianne, "what miserable nights have I passed!"9 Her anxiety was worsened by their financial

6 Marianne Hunt to Leigh Hunt, May 6, 1813.

7 Leigh Hunt to Marianne Hunt, October 23, 1813.

8 Marianne Hunt to Leigh Hunt, June 9, 1813.

9 Ibid, 
state. The Hunts were chronically poor. Now extra expenses of doctors, sickbeds, barley water, and jelly strained them to the limit. Distracted Marianne lost her purse and was obliged to consider pawning her watch. "Oh Henry," she wailed again to her husband, "this has been a trial indeed to your dear girl." 10

Meanwhile at Surrey Gaol, Hunt, though sunk in melancholy, fared rather better. Indeed, whereas one might expect imprisoned Hunt to be the object of sympathy, it is Marianne who more readily commands a biographer's compassion. Friends and relatives supported Hunt to the utmost. He continued to edit the Examiner: in fact he had taken on an even heavier burden of its composition, relinquishing only those articles he could not possibly cover-like theatre reviews-in the hope that the added work would cure his depression. He found writing satisfied him, and the compositors were astounded by his industry. Of course there were bad days, when the blood beat in his head and even ginger beer could not stifle his surfeit of bile, and when a fever and sore throat failed to respond to rubbings with hartshorn and laudanum. But a regular routine of exercise and study and a constant flow of society helped. His family had devised a support system of mammoth ramification. He was seldom alone and prison was like a tolerant lodging house. First came his relatives and old friends, gossiping, quarreling, eating, drinking. It was nothing to have six visitors of a morning with more expected later. His sisterin-law became a resident housekeeper and his two nephews alternated as chaperoning houseguests. Few evenings passed without wine and music and "bustling talk and merriment,"11 with a troop of friends to be lighted out at ten o'clock curfew by the gaoler, with a few left behind to sleep on the sofas. No wonder that Marianne, solitary at Brighton, remarked tartly that she hoped he did not overtire himself.

By now Hunt had begun to hold a prison court, and in progressive circles it became fashionable to be seen in Leigh Hunt's prison room. Old friends brought new ones, and Hunt's lawyer, Henry Brougham, introduced the political economist, Jeremy Bentham, who played battledore with the children. Charles and Mary Lamb-old literary friends-brought food and poems and the journalist William Hazlitt, who waited deferentially outside the door to be welcomed. The starving artist Benjamin Haydon came for breakfast and dinner and fetched his giant painting the Judgment of Solomon for inspection. In the middle of May, Thomas Moore, the rising, radical-minded poet,

10 Ibid.

11 Leigh Hunt to Marianne Hunt, April 24, 1813. 
already a warm friend, introduced Hunt's most celebrated caller, a handsome young poet whom Hunt had distantly seen bathing near Westminster Bridge years before. This was Lord Byron, and Hunt was agog, partly because he loved a lord, partly because by 1813 Byron was London's most fashionable poet and lover, and partly because they were alike devoted to literature and liberalism.

On May 19 Byron came with Moore to Hunt's prison rooms and a few days later he called alone. The day before his first visit Byron sent Moore verses which have come to immortalize Hunt's imprisonment.12

But now to my letter-to yours 'tis an answer-

To-morrow be with me, as soon as you can, sir,

All ready and dress'd for proceeding to spunge on

(According to compact) the wit in the dungeon. ...

The wit in the dungeon! It was a poetic rather than a true description, but in his journal at the end of 1813 Byron did make a shrewd prose assessment of Hunt's character. He liked and admired him, seeing him as an extraordinary libertarian of considerable spirit and attraction. Byron also recognized Hunt's masochistic sense of martyrdom, his ingenuous immaturity, and his irritating authoritarianism. Hunt, in his letters to Marianne, interpreted Byron's character much less accurately. He saw a spirit kindred to his own, but corrupted by society, whose health might yet be restored by the assistance of his own superior example. He even confided a part for Marianne in this scheme of reformation. Byron had known only frivolous society women, never a good, domestic wife: Marianne's virtuous example might also render Byron's heart and understanding a service. But Marianne was dubious. She had heard too many rumors concerning the poet's profligate life. From the distance of Brighton, she was unconvinced by Hunt's glowing description and predisposed to dislike Lord Byron: an opinion she never found reason to alter. Poor Hunt! His crusading letters showed how badly he had misread both Byron's and Marianne's natures. From these earliest epistolary beginnings, a stormy threefold relationship could easily be prophesied.

Then suddenly the separation was over. Thornton recovered, John was well, and they all returned to Surrey Gaol. It was not a long reunion, for a few months later John and Marianne were ill and another brief separation was necessary. But Hunt could cope, and in

12 The Poetical Works of Lord Byron (London: Oxford University Press, $1945)$, p. 70. 
these two imprisoned years he in fact coped better than he would ever do again in his life. Emotionally and professionally these were perhaps his greatest years, and for insight into his personal feelings we are indebted to those precious marital letters preserved in The University of Iowa Libraries. 
match her own), I continually met with afterwards in the land of her ancestors. Her veil, and her baskets of flowers, used to come through the portal, like light.

I must not omit tho-henen a visit from the 8 venerable Bentham, who was justly said to unite the wisdom of a sage with the simplicity of a child. 1 hat hat found me playing at battledore, in which he took a the howow of part, and, with his usual eye towards improvement, ne from him suggested an amendment in the constitution of efore shuttlecocks. I remember the surprise of the go-fore
vernor at his local knowledge and his vivacity. "Why, Mister," said he, "his eye is everywhere at when he come once."

All these comforts were embittered by unceasing All these comforts were embittered by unceasing
ill-health, and by certain melancholy reveries, which
the nature of the place did not help to diminish. Sesme the During the first six weeks, the sound of the felons' $q_{x \text { sminer }}$ had chains, mixed with what I took for horrid execra- $\frac{1}{\text { tholken wele }}$, tions or despairing laughter, was never out of my/poken well a
ears. When I went into the infirmary, which stood/ sed wephly between the jail and the prison walls, gallowsespeper. On $/ 4$ were occasionally put in order by the side of my windows, and afterwards set up over the prisonf fresent ocensing gates, where they remained visible. The keeperke one day, with an air of mystery, took $\mathrm{mg}$ into the upper ward, for the purpose, he said, of' gratifying me with a view of the country from the foof. Some-

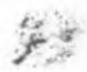

